\title{
Authentic Assessment Implementation on Curriculum 2013: Types and Its Washback
}

\author{
Ni Made Anggi A. Putri1*, nimadeanggi@gmail.com , Institut Agama Hindu Negeri \\ Tampu Penyang Palangka Raya \\ Riyadi Santosa, Universitas Sebelas Maret \\ Dewi Rochsantiningsih, Universitas Sebelas Maret
}

\begin{abstract}
A significant change in education instructional goals effects assessment techniques used to evaluate students' progress. The root of this phenomenon highly offers to authentic assessment as an alternative assessment. This study deals with authentic assessment implementation and its effects within teaching and learning in the context of Year 7 English students. It employs case study to get a in-depth understanding of the case. Data of the study were gained from deep-interview, observation, and document analysis. While, the data were analyzed by using Interactive model involving data reduction, data displays and conclusions: drawing/verification. The study finds that the relevance of implementation of authentic assessment becomes the main factor of determining its washbacks. Since most the authentic assessment stages undertaken by teachers are in line with National Regulation on how the assessment is designed and implemented, it provides more positive washbacks for both teachers and students such as motivated to be more creative and innovative in teaching and learning process. Nevertheless, the administration of assessment as guided by the government had a negative effect to teachers since it makes them feel overburdened and stressed.
\end{abstract}

Keywords: authentic assessment, curriculum, washback Effect

\section{INTRODUCTION}

Recently, a significant change in education instructional goals stimulates the change of assessment techniques used to evaluate its progress. Scholars always try to look for the appropriate one to assess their students to meet the goals. It moves toward more authentic method (Frey, Schmitt, \& Allen, 2012; Svinicki 2004). Currently, the need of alternative assessment instrument is also growing in Indonesia. The 2013 Curriculum (K-13) highlights the shift of teaching approach and assessment system to be more authentic. In its update, Permendikbud no. 23/2016 (Permendikbud Republik Indonesia, 2016) Regulation requires teachers to engage with authentic assessment in evaluating students' competences in order to improve the quality and competitiveness of the nation.

The authentic assessment as an alternative assessment is suggested more applicative and meaningful since students must be able to face challenges in real life (Pantiwati, 2013). The authentic assessment refers to the cognitive process and products considered important in real life (Palm, 2008). Since the authentic assessment emerged from constructivism approach, it provides opportunities for learners to construct and apply their competence in real activities

99 | IJET $\mid$ Volume. 10, Issue 1. July 2021

Copyright 2021 Ni Made Anggi A. Putri, Riyadi Santosa, and Dewi Rochsantiningsih are licensed under Creative Commons Atrribution-ShareAlike 4.0 International License. 
(Aliningsih \& Sofwan, 2015). It involves deeply understanding the thinking, the motivation, and the actions of various cultures that contribute to global awareness (Retnawati et al, 2016). A variety of alternative methods itself emerges to authentic assessment that allow students to demonstrate their ability in completing task and problem solving (Hidayati, 2016). Authentic assessment focuses on how students can consider and what skills they can apply to various contexts (Whitlock \&Nanavati, 2013). Thus, authentic assessment provides the yardstick for how students apply their skills and what they achieve in real life setting.

Authentic assessment has become increasingly used in education and has even begun the most interesting research issues among stakeholders. Literatures have revealed that authentic assessment has great benefit for both teachers and learners (see e.g Aliningsih \& Sofwan, 2015; Retnawati et al., 2016). It provides opportunities for learners to construct and apply their competence in real activities (Aliningsih \& Sofwan, 2015). Moreover, it involves deeply understanding the thinking, increase motivation, and solving the problem (Retnawati et al., 2016). By using authentic assessment, it encourages learners' autonomy and motivation both in learning and assessment process (Brown, 2004; O’Malley \& Pierce, 1996).

Meanwhile, as a new assessment method, authentic assessment has several challenges dealing with its implementation encountered by the stakeholders. In implementing authentic assessment, it should include an assessment of attitudes, skills, and knowledge (Pardimin, 2018). The study by Komarudin (2015) suggested that the implementation of authentic assessment is not optimal since some problems encountered by teachers. The educators do not seem to fully understand the assessment system e.g. developing the instrument, formulating the indicators, and designing the scoring rubric (Nurgiyantoro, 2011; Retnawati, Hadi \& Nugraha, 2016). Pardimin (2018) reported that the ability of teachers in documenting the assessment that has been done is still in sufficient categories. This might because the teachers only take the value and missed the important part for improvement namely following up the results.

In one other study, lack of teachers' competences in authentic assessment and preferences in using summative assessment are also mentioned as teachers' problem regarding the implementation (Kurebwa \& Nyaruwata, 2013). Moreover, in the teaching process, the teachers tend to adapt the policy regarding their classroom situation even though their implementation from the planning to the assessing process indicated a strong point of the K-13 (Ahmad, 2014). One way of getting better understanding is through professional development program as Training and workshop on K-13 provided by the government (Pardimin, 2018). However, Arbie, Talib and Mohammad, (2015) in his study, for example, revealed that the training on K-13 implementation more than just three days. It means that the training does not cover all information and aspects in K-13 (Arbie, Talib \& Mohammad, 2015). In other words, teachers could not get better understanding in implementing authentic assessment. Thus, in this situation, teachers do not have confident to carry out the thorough $\mathrm{K}-13$, nor to mention the authentic assessment as required in the K-13.

Based on description above, the point of implementation of authentic assessment problem is the inappropriateness of teacher understanding of authentic assessment itself. Teachers feel uncomfortable over the implementation of authentic assessment. As a result, there is imbalance of what should be done and what is not to do. They are finally trapped to modify the policy regarding their classroom situation (Ahmad, 2014). In principle, the inappropriate implementation of authentic assessment has been the root of problem of unsuccessfully authentic assessment process. This is also in line with what washback effect occurs since Assessment and 100 | IJET| Volume. 10, Issue 1. July 2021

Copyright 2021 Ni Made Anggi A. Putri, Riyadi Santosa, and Dewi Rochsantiningsih are licensed under Creative Commons Atrribution-ShareAlike 4.0 International License. 
test are always along with their effects (Watanabe \& Curtis, 2004). Thus, the intention of this study is to analyze: firstly, the implementation of authentic assessment includes types of authentic assessment as well as the way how teachers implement authentic assessment in their English classroom, and secondly, the washback affects occurs in teaching- learning process.

\section{METHOD}

This study adopted descriptive case study approach to get a in-depth understanding about authentic assessment implementation in one of pilot school in Surakarta. Case studies usually include a small sample of participants in a relatively small controlled environment (Tsang, 2014). Moreover, Simons (2015) argued that Case study is the study of the singular, the particular, the unique, whether that single case is a person, a project, an institution, a program or a policy. (p. 175). Thus, The study was conducted at an Islamic junior high school which involved all English teachers who teach seventh grade (two teachers) and all the seventh grade students of junior high school of a pilot school in Surakarta, Indonesia. Purposive sample technique was used in determining the sample in this research. This school was chosen as the place for this research considering it is one of piloting school for K-13 in Surakarta, Central Java. Therefore, the theoretical orientation of this research rests on descriptive case study.

Data sources were obtained through interviews, observation, and documentation. The researchers conducted participant observation in order to obtain concrete activities of authentic assessment implementation. Through documentation, researchers obtained written data about school profiles, curriculum, programs, assessments used and so on. The interview questions were related to the implementation of authentic assessment and also its effects in thirty semi-structure questions.

In analyzing the data, The study adopts interactive model proposed Huberman, Miles, and Saldana (2014) which involves three analysis components, namely data reduction, data displays and conclusions: drawing/verification . After the data were sorted in data reduction, the researchers present the data in a narrative which can explain problems and objectives of the study. The last stage of data analysis is drawing conclusion and doing verification. In drawing conclusions, the researchers tried to looking for patterns and themes so that can be used as research findings. Moreover, the researchers verified the data to the theory and previous researches.

Meanwhile, the consistency of data can be verified through field note or authentic data that were collected through interview, observation and document analysis. To obtain data validity, triangulation and member checking were used to get its validity where the data collected are also crossed checked and confirmed by informants in order to avoid manipulation of data and minimize misinterpretation.

101 | IJET| Volume. 10, Issue 1. July 2021

Copyright 2021 Ni Made Anggi A. Putri, Riyadi Santosa, and Dewi Rochsantiningsih are licensed under Creative Commons Atrribution-ShareAlike 4.0 International License. 


\section{RESULT AND DISCUSSION}

\subsection{Findings}

The findings are organized into two main parts: (1) the relevant of authentic assessment including types of authentic assessment used by teachers and how teachers implement authentic assessment in their English classroom, and (2) the description of the washback of authentic assessment to the teaching and learning process in the school.

\subsubsection{The Authentic Assessment Implementation}

\section{a. The Types of Authentic Assessment Used by Teachers}

The finding obtained from observation emerged that there are various types of assessment used by teachers in this research. Each teacher has implemented different kinds of assessment in their EFL Class as presented in Table 1.

Table 1 The Competence and Types of Assessment Used by Teachers in the EFL classroom

\begin{tabular}{|c|c|c|c|}
\hline \multirow{2}{*}{$\begin{array}{c}\text { Student } \\
\text { Competence }\end{array}$} & \multicolumn{2}{|c|}{ Technique of Assessment } & \multirow{2}{*}{ Instrument } \\
\hline & Teacher 1 & Teacher 2 & \\
\hline $\begin{array}{l}\text { Social Attitude } \\
\text { Competence }\end{array}$ & Observation & Observation & $\begin{array}{l}\text { Checklist with } \\
\text { rating scale }\end{array}$ \\
\hline $\begin{array}{l}\text { Knowledge } \\
\text { Competence }\end{array}$ & $\begin{array}{l}\text { Written test(daily test, } \\
\text { mid-test, final test), } \\
\text { homework, exercises }\end{array}$ & $\begin{array}{l}\text { Written test(daily test, } \\
\text { mid-test, final test), } \\
\text { homework, exercises }\end{array}$ & $\begin{array}{l}\text { List of questions } \\
\text { related to the } \\
\text { material }\end{array}$ \\
\hline Skill Competence & $\begin{array}{l}\text { Performance: role play, } \\
\text { retelling story, project } \\
\text { and exhibition, } \\
\text { portfolio, }\end{array}$ & $\begin{array}{l}\text { Performance: role play, } \\
\text { speech, writing } \\
\text { sample, project and } \\
\text { exhibition, portfolio }\end{array}$ & Scoring rubric \\
\hline
\end{tabular}

Although Table 1 shows that teachers use various ways to assess their students, this study focuses on the use of authentic assessment only. There are several types of authentic assessment used by teachers in this study including performance test, role play, retelling story, discussion and presentation, project and exhibition, writing sample and speech are found. Based on direct observation, interview followed with document analysis, it is revealed that types of authentic assessment chosen by teachers are based on their classroom characteristic. Thus, each teacher implemented different authentic assessment. Another factor dealing with types chosen by teachers is the newest regulation, the Indonesian Minister of National Education number 23 year 2016 (Permendikbud Republik Indonesia, 2016), which stated that teachers are allowed to use any kind of assessment based on their situation. Furthermore, the types of assessment used by teachers in their EFL classroom are also relevant with the syllabus of K-13 that the assessment form can be in performance test, observation, self-assessment, and portfolio in assessing students' out comes. Nevertheless, though self and peer-assessment has been claimed as a key element in authentic assessment (O'Malley \& Pierce, 1996), this present study has also revealed that both self and peer-assessment were found rarely used in authentic assessment by teachers. One factor to consider, gained from interview, is that the implementation of self and peerassessment is time consuming and also complicated in procedure.

102 | IJET| Volume. 10, Issue 1. July 2021

Copyright 2021 Ni Made Anggi A. Putri, Riyadi Santosa, and Dewi Rochsantiningsih are licensed under Creative Commons Atrribution-ShareAlike 4.0 International License. 
From this finding, it generally states that Indonesian teachers are not familiar with self and peer-assessment to assess their students' achievement. Consequently, it would perhaps be considered that teachers should implement both types of these assessments in their class because self and peer-assessment provide the opportunity for learners to develop an understanding of their own level of skill, knowledge, and readiness for task to their goal (Nunan, 2004). It is also supported by Brown (2004) who argues that self and peer-assessment offer certain benefits such as direct involvement of students to their destiny, encouragement of autonomy, and increased motivation.

\section{b. The implementation of authentic assessment by teachers of seventh grade of English students}

To find out the relevance of authentic assessment implementation, documents and the teachers' designing process were analyzed. In this case, documents used in the implementation of authentic assessment included syllabus, lesson plan, and instrument. The document analysis focused on 1 basic competence and was followed by class observation for four meeting for each teacher. Documents used to guide the implementation of authentic assessment are syllabus, lesson plan, instruments and scoring rubrics.

Table 2 Document Used to Implement Authentic Assessment

\begin{tabular}{ccccc}
\hline \multirow{2}{*}{ Teacher } & \multicolumn{4}{c}{ Document used by teacher in implementing authentic assessment } \\
\cline { 2 - 5 } & Syllabus & Lesson plan & Instrument & Scoring rubric \\
\hline Teacher 1 & $\sqrt{ }$ & $\sqrt{ }$ & $\sqrt{ }$ & $\sqrt{ }$ \\
Teacher 2 & $\sqrt{ }$ & $\sqrt{ }$ & $\sqrt{ }$ & $\sqrt{ }$ \\
\hline
\end{tabular}

Table 2 shows that all teachers in this study share the same documents needed in the authentic assessment implementation. It implies that implementation of authentic assessment in this school is relevance to the National Regulation on assessment in terms of designing process, implementation process, and evaluation. In the designing stage, firstly, teacher analyzed the core and basic competences together in group discussion. Then, they developed their own material, learning activities, and scoring rubric based on the competence. This, as the teachers reported, makes the class more enjoyable, more fun, and creative. The teachers' steps to plan the authentic assessment are in line with those proposed by O'Malley and Pierce (1996) that to design a well-functioning authentic assessment, teachers should (1) build a team to discuss the assessment program, objective, and role in instruction and in school, (2) determine the purpose, (3) specify objectives, (4) conduct professional development where designing team share information about the rational for authentic assessment, (5) collect examples, (6) develop a new assessment, (7) try out and review the assessment.

In implementing authentic assessment, teachers employed strategies in three stages namely planning, implementing, and evaluation. In the planning step, teachers analyzed the core and basic competence, and selected the indicators. After determining the indicators, they started to make the instruments and scoring rubric. In the implementation process, the teachers applied authentic assessment covering all aspect mandated by K-13. In assessing

103 | IJET| Volume. 10, Issue 1. July 2021

Copyright 2021 Ni Made Anggi A. Putri, Riyadi Santosa, and Dewi Rochsantiningsih are licensed under Creative Commons Atrribution-ShareAlike 4.0 International License. 
students' attitude, the teachers conducted observation which was done during the teachinglearning process. In observation process, teachers assess students' social attitude including honesty, self-confidence, responsibility, cooperation and discipline. Then, teachers also assessed students' knowledge by using written test. The lists of questions are about descriptive text. The students were given the descriptive text and were asked to identify the language feature of the function of itself.

The last aspect that was assessed is students' skill. In assessing students' English skills, the teachers used various types of authentic assessment as mention before. Taking example of the most frequently used of authentic assessment, student project, the procedure of implementation based on observation to teacher 1 revealed that the implementation covered some steps. The project assessment was conducted by giving the students task in drawing a person, futuristic tool, or robot. Firstly, teacher 1 explained the competences and indicators. Secondly, she delivered the criteria that would be assessed. Thirdly, she divided students into group work. She asked them to discuss in group while she was assessing students' attitude. She gave her students chance to explore their knowledge and be creative in doing the project. After making drawing or robot, the students are required to present their product in the class. Through the presenting their products, teacher 1 assessed students' English skill. In the evaluation stage, teacher gave feedback and used the result of assessment as reflection. The designing process and the implementation of authentic assessments are relevant to the principle of authentic assessment where the teachers conduct assessment during the learning process, and also cover the entire competency aspects used appropriate assessment technique for monitoring and measure the students' achievement. This study also identified that teachers did not make completed assessment tool for all of assessment used. The reasonable factor is the fact that designing effective authentic assessment needs extra time, more money, and group of more teachers.

\subsubsection{The washback of the implementation of authentic assessment on teaching-learning process}

Since the test and assessment are always coming up with the effect, it is needed to explore the effect of authentic assessment through this study. The finding reveals that implementing authentic assessment brings some effects not only to teachers and students but also teaching content. The study suggest that authentic assessment implementation brings several impact on teaching and learning process especially impact (1) on student, (2) on teacher, and (3) on teaching content. The interesting point highlighted by the finding of this research is that the implementation of authentic assessment gives more positive effect to students, teachers and also the teaching materials. It is found that the enjoyable and challenging learning environment derived by authentic assessment is engaged the students more active, confidents, and think creatively. The effect of authentic assessment in teaching learning process can be illustrated in Table 3.

Table 3 The Effect of Authentic Assessment in Teaching Learning Process

\begin{tabular}{ccc}
\hline Area & The effect of authentic assessment & Types of washback \\
\hline Teacher & Encouraged to be more creative and innovative & Positive washback \\
& Being motivated to upgrade herself & Positive washback
\end{tabular}

104 | IJET| Volume. 10, Issue 1. July 2021

Copyright 2021 Ni Made Anggi A. Putri, Riyadi Santosa, and Dewi Rochsantiningsih are licensed under Creative Commons Atrribution-ShareAlike 4.0 International License. 
Being stressful of completing the administration

Students

Teaching content in the learning activities

Improved Students' English skill

Developed students' soft skill

Felt fun and enjoy during learning process

Encouraged students' critical thinking theme of activity
Encouraged to be more active, motivated and creative

Teacher used update material and hot issue as the

Teacher gave additional materials that are relevant

with the topic discussed

Teacher modify the material by giving video or other

things to encourage students in interesting learning

process
Negative washback

Positive washback

Positive washback

Positive washback

Positive washback

Positive washback

Positive washback

Positive washback

Positive washback

\subsection{Discussion}

\subsubsection{The Authentic Assessment Implementation}

Based on the finding above, several types of authentic assessment used by teachers are noted in this study e.g. performance test, role play, retelling story, discussion and presentation, project and exhibition, writing sample and speech are found. This finding is relevant with Aliningsih and Sofwan's work (2015) which found that written and task-based assessment, performance test, and observation are the most preferred used in assessing students' outcomes. It is also in line with Hidayati's finding (2016). She found that the assessments used by teachers of twelfth grade are written test, performance test, product and portfolio, and observation (Hidayati; 2016). Meanwhile, this present study has noted that both self and peer-assessment were found rarely used by teachers in the class. One factor to consider, gained from interview, is that the implementation of self and peer-assessment is time consuming and also complicated in procedure. This finding is similar with research result of Hidayati (2016).

Due to authentic assessment implementation, it implies that implementation of authentic assessment in this school is relevance to the National Regulation on assessment in terms of designing process, implementation process, and evaluation. The researchers found that teachers carried out various strategies in three stages namely planning, implementing, and evaluation. These steps are in line with O'Malley and Pierce's (1996). They argued that to design a well-functioning authentic assessment, teacher should (1) build a team to discuss the assessment program, objective, and role in instruction and in school, (2) determine the purpose, (3) specify objectives, (4) conduct professional development where designing team share information about the rational for authentic assessment, (5) collect examples, (6) develop a new assessment, (7) try out and review the assessment (O’Malley \& Pierce, 
1996). The designing process and the implementation of authentic assessments done by the teachers are also relevance with the Indonesian Minister of National Education number 23 year 2016 (2016) and the principal of authentic assessment where the teachers conduct assessment during the learning process. It also covers the entire competency aspects used appropriate assessment technique for monitoring and measure the students' achievement.

However, this study also identified that teachers did not make completed assessment tool for all of assessment used e.g. scoring rubric. Since authentic aseessment is a complex concept, it could be an exhausting task for teachers (Kartowagiran,Wibawa, Alfarisa,\& Purnama, 2019). On the other words, the fact that designing effective authentic assessment needs extra time, more money, and group of more teachers. Moreover, the inconsistency of the regulation dealing with assessment also contribute as a problem. The change of assessment regulation is not easily understood by the teachers and is not easy to implement the assessment in the recommended procedure. This finding is familiar as reflected from Retnawati et al.'s finding (2016) that the teachers' difficulties are also found in acquiring the instrument of attitude, caring out the authentic assessment, developing the instrument and rubric for skills.

Furthermore, teachers also deal with some problems in implementing authentic assessment. Teachers felt overburdened with administration and too many assessment formats. This finding is similar with results study by Cheung and Wong (2012) which suggested that the teachers tended to have heavy workloads. In other literature, Lumadi (2013) argued that variety of method in assessing is noted as problem in alternative assessment. This is in line with the present result that teachers encountered difficulties in choosing appropriate technique and instrument of assessment. This study also revealed that teachers have lack of knowledge in making scoring rubric and comprehensive understanding regarding to current regulation. The findings are also similar with the results of research by Alshammari (2013), Eraslan (2013), Lumadi (2013), Kurebwa and Nyaruwata (2013), and Retna wati et al. (2016). Furthermore, lack of facilities and simple material are also noticed as problems encountered by teachers. These findings is relevant with Syomwene's finding (2013) which revealed that teachers encountered various problems such as lack of facilities, institutional leadership, ability and inability to evaluate, lack of infrastructure, etc.

Meanwhile, to overcome the problems, teachers regularly have had discussion section with other teacher, curriculum coordinator and joined seminar of K-13 as revealed in interview section. They also tried to build good communication with students in order to help students to understand what to deal with the assignment and can prepared it well during the semester. The students played important role the authentic assessment implementation. As reported in result finding of Pardimin (2018), students could perform better learning activity when they initialy how they wouldbe assessed. Dealing with the simple material, teacher usually modified the material and adding some information related to the topic to the teaching material. Indirectly, alternative assessment tends to improve teachers' teaching skill by upgrading themselves with many kinds of teaching method. They become more creative in designing the teaching-learning activities. The teachers modified the materials, and also used several methods to get students' attention. It is similar with by Pang (2009) who states that the assessment integrates meaningful and innovative learning activities in teaching

106 | IJET| Volume. 10, Issue 1. July 2021

Copyright 2021 Ni Made Anggi A. Putri, Riyadi Santosa, and Dewi Rochsantiningsih are licensed under Creative Commons Atrribution-ShareAlike 4.0 International License. 
methodologies devote more attention to students' intentions, interests, and choices, encouraged and motivated student to work harder. Teachers are also motivated to be more skillful by upgrading themselves in seminar, group discussion etc. due to the implementation. This finding is in line with Darling-Hammod and Snyder (2000) who argue that instead of implementing set routines, teacher need to become ever more skillful in their ability to evaluate teaching situation and developing teaching response. In sum, the highlight factors of these problems are lack of teachers' understanding about authentic assessment. Therefore, the problem might be overcome by providing proffesional development program such as workshop, training seasons and expert coaching by government.

\subsubsection{The Washback of the Implementation of Authentic Assessment on Teaching- Learning process}

Taking a deeper look at alternative assessment's washback, the data from direct observation, interview, and document analysis are used and corroborate each other that implementation of authentic assessment brings some impact on teaching-learning process. Even both positive and negative washback occur on the implementation, the authentic assessments bring much more positive effect on teaching-learning process, especially to learners. The authentic assessment implementation strongly influences on improving students' interest, active, motivation, creativity, self-confidence and also their English ability. This result finding is in line with Alderson and Wall (1993) who argue there are 15 possible hypothesis where test will affect teaching, learning, what teachers teach, how teachers teach, what learners learn, how learners learn, the rate and sequence of teaching and sequence of learning, degree and depth of teaching and of learning, attitudes to the content and method of teaching and learning.

Moreover, it is also found that the enjoyable and challenging learning environment derived by the implementation required the students more active, confidents, and think creatively. This finding is relevant with Minta's finding (2003) which suggest that there is an improvement in students' self-concept, motivation and skill achievement when using different teaching method and authentic assessment. The finding is also supported by Brown (2004) who statements that assessment can increase self-confidence and intrinsic motivation. The various and challenging authentic task made by teacher have also improved students' motivation in learning English. The present finding is also similar with result of Gulikers, Bastiaens and Kirschner's work (2004) which state that the authentic assessment makes students actively to demonstrate what they learning by creating a product and having real life experienced.

The implementation of authentic assessment this study in grade 7 has improved students creativity, critical thinking and to be more confident since the tasks given by teacher are challenging, students are required to be creative as they can and think creatively. It is relevant with Fook and Sidhu (2010) who state that many benefits can be reaped from authentic assessment, for example, portfolio encourages learners to reflect on auto self learning, the project requires students to learn from doing and think critically, and the presentation facilities the students to more confident and communicative in front of the audient. Furthermore, the implementation of authentic assessments also facilitate students to perform their skill during the learning process as Darling-Hammond \& Snyder (2000) state that authentic assessment practice includes number of opportunities for the students and teacher to learn and practice according to

107 | IJET| Volume. 10, Issue 1. July 2021

Copyright 2021 Ni Made Anggi A. Putri, Riyadi Santosa, and Dewi Rochsantiningsih are licensed under Creative Commons Atrribution-ShareAlike 4.0 International License. 
the desired outcomes. Hence, students also have more opportunities to apply their English skill in the class and their English skills are getting better since they use English much often in the class. These facts are in line with the finding of Jampel et.al (2016) who conducted a research of the effect of implementation ICT based authentic assessment by 2013 curriculum. They revealed that learning outcome from students which is learned through authentic assessment development process by $\mathrm{K}-13$ is higher than learning outcome from students which is learned through conventional assessment.

The washback can also be seen in teachers. The educators are motivated to be more creative and innovate in designing their teaching activity by modifying material and adding more information related the topic. They also enrich themselves with teaching methodology so that the students can pay more their attention to the classroom activity. This indicates that authentic assessments give positive impact to teacher. It is similar with by Pang (2009) who states that the assessment integrates meaningful and innovative learning activities in teaching methodologies devote more attention to students' intentions, interests, and choices, encouraged and motivated student to work harder. Teachers are also motivated to be more skillful by upgrading themselves in seminar, group discussion etc. due to the implementation. This finding is in line with DarlingHammod and Snyder (2000) who argue that instead of implementing set routines, teacher need to become ever more skillful in their ability to evaluate teaching situation and developing teaching response.

\section{CONCLUSION}

Based on the description of research finding above, it is generally stated that the relevance of implementation of authentic assessment is integrated with the washback effects occurred in teaching-learning process. This study revealed that the implementation of authentic assessment in the pilot school is relevant with the standard regulation of K-13. The results of this study suggest that the relevance of implementation is directed growing in line with the teachers' competence and understanding about authentic assessment. This study also found that both teachers and students get more positive advantages and effects. However, the consideration of optimizing the result of assessment for developing teaching-learning process is still lack. Therefore, the study might be taken as consideration to Indonesian government to provide professional development program for English teacher in authentic assessment due to leading the success of implementation of Curriculum 2013. Regarding its limitation of the study, analyzing more specific type of authentic assessment and its washback are needed to conduct for future research.

108 | IJET| Volume. 10, Issue 1. July 2021

Copyright 2021 Ni Made Anggi A. Putri, Riyadi Santosa, and Dewi Rochsantiningsih are licensed under Creative Commons Atrribution-ShareAlike 4.0 International License. 


\section{REFERENCES}

Abu naim, H., A. Samah, N., \& Talib, R. (2016). The Singing Method in Teaching and Learning Process in Helping Students to Master Arabic Lexical.

Ahmad, D. (2014). Understanding the 2013 Curriculum of English Teaching through the Teachers' and Policymakers' Perspectives. International Journal of Enhanced Research in Educational Development (IJERED), 2(4), 6-15. http://repositori.uinalauddin.ac.id/id/eprint/15304

Alderson, J., \& Wall, D. (1993). Does Washback Exist. Applied Linguistics, 14(2), 115-129. https://doi.org/10.1093/applin/14.2.115

Aliningsih, F., \& Sofwan, A. (2015). English Teachers' Perceptions and Practives of Authentic Assesment. Journal of Language and Literature, 1(10), 19-27. http://journal.unnes.ac.id

Alshammari, A. (2013). Curriculum Implementation and Reform: Teachers' Views About Kuwait's New Science Curriculum. David Publishing Company, 3(3), 181-186. https://doi.org/10.17265/2161-6248

Brown, G. T. L. (2004). Teachers' conceptions of assessment: implications for policy and professional development, Assessment in Education: Principles, Policy \& Practice. Routledge. https://doi.org/10.1080/0969594042000304609

Cheng, L., Watanabe, Y., \& Curtis, A. (2004). Washback in Language Testing: Research Contexts and Methods. Lawrence Erlbaum Associates.

Cheung, A. C., \& Man Wong, P. (2012). Factors Affecting The Implementation of Curriculum Reform in Hong Kong: Key Findings From a Large-Scale Survey Study. International Journal of Educational Management, 26(1), 39-54.

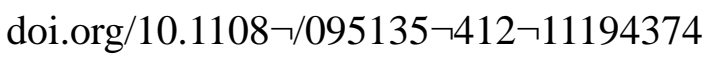

Darling, L., Hammond, S. J. (2000). Authentic Assessment of Teaching in Context. Teaching and Teacher Education, 16, 523-545. doi.org/10.1016/S0742-051X(00)00015-9

Standard Penilaian Pendidikan, Pub. L. No. 23 (2016).

Eraslan, A. (2013). Teachers' Reflections on the Implementation of the New Elementary School Mathematics Curriculum in Turkey. Hacettepe Üniversitesi Eğitim Fakültesi Dergisi, 28(2), 152-165. https://dergipark.org.tr/en/ᄀpub/hunefd/issue $\neg / 7790 / 101873$

Fook, C. Y., \& Sidhu, G. K. (2010). Authentic Assessment and Pedagogical Strategies in Higher 109 | IJET| Volume. 10, Issue 1. July 2021 Copyright 2021 Ni Made Anggi A. Putri, Riyadi Santosa, and Dewi Rochsantiningsih are licensed under Creative Commons Atrribution-ShareAlike 4.0 International License. 
Education. Journal of Social Sciences, 6(2).

Frey, B. B., Schmitt, V. L., \& Allen, J. P. (2012). Defining Authentic Classroom Assessment. Practical Assessment, Research \& Evaluation, 17(2). https://scholarworks.umass.edu/pare/vol17/iss1/2

Gulikers, J., Bastiaens, T., \& Kirschner, P. (2004). A Five-Dimensional Framework for Authentic Assessment. Educational Technology Research and Development, 52(3). doi.org/10.1007/BF02504676

Hidayati, N. (2016). The Authenticity of English Language Assessment for the Twelfth Graders of SMK (Vocational High School) Negeri 4 Surakarta. PREMISE JOURNAL, 5(1). doi.org/10.24127/pj.v5i1.429

Huberman, A. M., Miles, M., \& Saldana, J. (2014). Qualitative data analysis: A methods sourcebook. SAGE Publications.

Jampel, I. Nyoman \& Widiana, I. W. (2016). The Effect of Implementation Authentic Assessment Development Result based on ICT Toward Student's Learning Outcome in Learning Process by 2013 Curriculum. I.J. Modern Education and Computer Science, 5, 320-338. https://doi.org/10.5815/ijmecs.2016.05.04

Kartowagiran, B., Wibawa, E. A., Alfarisa, F., \& Purnama, D. N. (2019). Can Student Assessment Sheets Replace Observation Sheets? Cakrawala Pendidikan, 38(1), 33-44. doi: https://doi.org/10.21831/cp.v38i1.22207

Komarudin. (2015). Penilaian Autentik pada mata Pelajaran Pendidikan Agama Islam dan Budi Pekerti (Studi Analisis Kurikulum 2013 Kelas VIII Semester 1 di SMP Negeri 4 Yogyakarta Tahun Pelajaran 2014/2015). UIN Sunan Kalijaga.

Kurebwa, M., \& Nyaruwata, L. T. (2013). Assessment Challenges in the Primary Schools: A Case of Gweru Urban Schools. Greener Journal of Educational Research, 3(7), 336-344.

Mintah, J. K. (2003). Authentic Assessment in Physical Education: Prevalence of Use and Perceived Impact on Students' Self-Concept, Motivation, and Skill Achievement. Measurement in Physical Education and Exercise Science, 7(3), 161-174. doi: 10.1207/S15327841MPEE0703_03

Muhammad, T. (2008). Investigation of The Factors that Cause Language Anxiety for ESL/EFL Learners in Learning Speaking Skills and The Influence It Cassts On Communication in The

110 | IJET| Volume. 10, Issue 1. July 2021 Copyright 2021 Ni Made Anggi A. Putri, Riyadi Santosa, and Dewi Rochsantiningsih are licensed under Creative Commons Atrribution-ShareAlike 4.0 International License. 


\section{Target Language.}

Nunan, D. (2004). Task-based Language Teaching. Cambridge University Press.

Nurgiyantoro, B. (2011). Model Penilaian Otentik dalam Pembelajaran Bahasa. Litera, 10(2). https://doi.org/10.21831/ltr.v10i2.1157\%0A

O'Malley, J.M., and Pierce, L. V. (1996). Authentic Assessment for English Language Learners: Practical Approaches for Teachers. Addison-Wesley Publishing Company.

Palm, T. (2008). Performance Assessment and Authentic Assessment: A Conceptual Analysis of The Literature. Practical Assessment, Research \& Evaluation, 13(4), 1-11.

Pang, Y. (2009). A Review of Washback and Its Pedagogical Implications. Phi VNU Journal of Science, Foreign Languages, 25, 257-263. https://js.vnu.edu.vn/FS/-article/view/2441

Pantiwati, Y. (2013). Authentic Assessment for Improving Cognitive Skill, Critical-Creative Thinking and Meta-Cognitive Awareness. Journal of Education and Practice, 4(14), 1-9. https://iiste.org/Journals/index.php/JEP/article/view/6790

Pardimin, P. (2018). Analysis Of Indonesian Mathematics Teachers' Ability In Applying Authentic Assessment. Cakrawala Pendidikan, 2. https://doi.org/10.21831/cp.v37i2.18885

Retnawati, Heri \& Hadi, Samsul \& Nugraha, A. (2016). Vocational High School Teachers' Difficulties in Implementing the Assessment in Curriculum 2013 in Yogyakarta Province of Indonesia. International Journal of Instruction, 9, 33-48. https://doi.org/10.12973/iji.2016.914a

Simons, H. (2015). Interpret in Context: Generalizing from The Single Case in Evaluation. Evaluation, 21(2), 173-188. https://doi.org/10.1177/-1356389015577512

Syaiful Arbie. (2015). The English Teachers' Perception of the Implementation Curriculum 2013 in SMK Negeri 1 Limboto. Universitas Negeri Gorontalo.

Syomwene, A. (2013). Factors Affecting Teachers' Implementation of Curriculum Reforms and Educational Policies in Schools: The Kenyan Experience. Journal of Education and Practice, 4(22), 80-86.

Tsang, E. W. (2014). Generalizing from research findings: The merits of case studies. , 16(4), 369-383. From doi: International Journal of Management Reviews, 16(4), 369-383.

Whitlock, B., \& Anavati, J. (2013). A Systematic Approach to Performative and Authentic Assessment. Reference Services Review, 41(1).

111 | IJET| Volume. 10, Issue 1. July 2021 Copyright 2021 Ni Made Anggi A. Putri, Riyadi Santosa, and Dewi Rochsantiningsih are licensed under Creative Commons Atrribution-ShareAlike 4.0 International License. 